\title{
GAYA KEPEMIMPINAN PEREMPUAN (Studi Pada Ketua OSIS diSMA Se-Jakarta Timur)
}

\author{
Sri Wahyuningsih ${ }^{1}$ \\ Susi Fitri S.Pd, M.Si, Kons ${ }^{2}$ \\ Dr. Gantina Komalasari, M.Psi ${ }^{3}$
}

\begin{abstract}
Abstrak
Penelitian ini bertujuan untuk mengetahui gaya kepemimpinan perempuan (studi pada ketua OSIS di SMA se-Jakarta Timur). Penelitian ini menggunakan metode survei. Subyek dalam penelitian ini adalah ketua OSIS perempuan di SMA wilayah Jakarta Timur sebanyak 32 orang di 123 SMA yang terdapat di wilayah Jakarta Timur dari 40 SMA Negeri dan 83 SMA Swasta. Pengumpulan data dilakukan dengan menggunakan instrumen gaya kepemimpinan yang dibuat berdasarkan teori dari Ronald Lippit and Ralp K. White yang menyatakan bahwa ada 3 gaya kepemimpinan yaitu otoriter, demokratis, laissez faire. Telah diuji validitas dan reliabilitasnya. Menghasilkan 56 butir pernyataan yang valid dan 38 butir pernyataan yang tidak valid dari 94 keseluruhan butir pernyataan, agar instrumen lebih proposional maka setiap indikator hanya terdiri 2 butir pernyataan yang valid sehingga didapat 66 butir pernyataan sedangkan reliabilitasnya sebesar 0,9501 yang berarti tinggi.Hasil Penelitian diketahui bahwa ketua OSIS yang menggunakan gaya kepemimpinan otoriter sebesar $31 \%$ yang artinya gaya kepemimpinan yang mempunyai kekuasaan pada seorang pemimpin. Kepemimpinan demokratis adalah pemimpin yang mempunyai kekuasaan secara bersama (ketua dan pengurus) sebesar 59\%. Sedangkan gaya kepemimpinan laissez faire 10\% yang artinya kepemimpinan laissez faire pada kemampuan untuk mempengaruhi orang lain agar bersedia bekerja sama dengan cara berbagai kegiatan yang akan dilakukan namun lebih banyak diserahkan kepada bawahan.Ketua OSIS perempuan masih jarang terdapat di SMA, oleh karena itu bagi guru BK harus mampu memfasilitasi siswa melalui layanan dan fungsi BK untuk melakukan layanan informasi, penempatan dan penyaluran untuk menyediakan pemenuhan kebutuhan siswa dan melihat potensi, bakat dan minat siswa, sehingga bagi siswa perempuan mempunyai peluang untuk menjadi pemimpin di berbagai organisasi di sekolah sebagai gerbang bagi siswa perempan untuk menjadi pemimpin. Implikasinya adalah dengan diketahuinya gaya kepemimpinan perempuan studi pada ketua OSIS, memberikan perluasan akses perempuan dalam mengembangkan kegiatan OSIS terutama pada kepemimpinan di Sekolah.
\end{abstract}

Kata Kunci : Gaya kepemimpinan, kepemimpinan perempuan, Ketua OSIS

\footnotetext{
Mahasiswa Jurusan Bimbingan dan Konseling FIP UNJ, sriwahyuningsih123@gmail.com

Dosen Bimbingan dan Konseling FIP UNJ, sriwahyuningsih123@gmail.com

3 Dosen Bimbingan dan Konseling FIP UNJ, gantina_komalasari@yahoo.com
} 


\section{Pendahuluan}

Kepemimpinan telah didefinisikan dalam kaitannya dengan ciri-ciri individual, perilaku, pengaruh terhadap orang lain, pola-pola interaksi, hubungan peran, tempatnya pada suatu posisi administratif, serta persepsi oleh orang lain mengenai keabsahan dari pengaruh. Ada berbagai isu yang terkait dalam pembahasan mengenai kepemimpinan perempuan, antara lain mengenai kesetaraan gender dan jenis kelamin. Kurangnya pemimpin perempuan disebabkan oleh adanya stereotip sosial yang menghambat perempuan untuk memimpin, padahal sebenarnya perbedaan kemampuan memimpin antara laki-laki dan perempuan itu tidaklah begitu besar. Misalnya perempuan kerap dianggap tidak dapat memimpin atau dalam kata lain tidak mempunyai potensi memimpin bila dibandingkan dengan laki-laki. Namun anggapan tersebut sebenarnya tidak dapat dibuktikan kebenarannya secara empiris.

Hal ini dapat dilihat di dalam negeri Presiden perempuan pertama di Indonesia Megawati Soekarno Putri, Gubernur perempuan pertama yang menjabat di daerah Banten Ratu Atut Chosiyah, Direktur Pelaksana Bank Dunia Sri Mulyani Indirawati. Adapun contoh didalam konteks dunia pendidikan, bahwa di provinsi DKI JAKARTA terdapat 116 SMA Negeri dari sekian sekolah terdapat 32 kepala sekolah perempuan dan 84 Kepala sekolah laki-laki. Sedangkan dari data survei di sekolah menengah atas yang peneliti lakukan terdapat 32 ketua OSIS perempuan dan 91 ketua OSIS laki-laki di SMA wilayah Jakarta Timur.

Menurut Eagly dan Johnson bahwa berdasarkan dari perbedaan sifat-sifat dasar gender, merumuskan gaya kepemimpinan otoriter dan demokratis adalah yang paling representatif didalam membedakan gaya kepemimpinan antara laki-laki dan perempuan apabila di lihat dari sudut pandang stereotip tentang gender maskulin yang menggambarkan sosok individu yang kuat, tegas dan berani adalah gambaran dari gaya kepemimpinan otoriter sedangkan gender feminin yang menggambarkan sosok yang memperlihatkan sifat-sifat yang hangat dalam hubungan personal, lebih suka berafiliasi dengan orang lain dari pada mendominasi adalah gambaran dari gaya kepemimpinan demokratis, maka yang perlu dipahami adalah kembali pada sudut pandang stereotip tentang perbedaan gender yang mengganggap lakilaki adalah maskulin sedangkan perempuan adalah feminin.

Dalam kepemimpinan perempuan pada ketua OSIS di SMA penting untuk diteliti tidak cuma karena perbedaan gender tetapi karena tantangan dalam bersaing dengan laki-laki untuk menjadi ketua OSIS itu tidak mudah perlu tanggung jawab yang lebih besar untuk menjadi seorang pemimpin, mendorong perluasan akses bagi perempuan untuk menjadi pemimpin, adanya kesetaraan laki-laki dan perempuan, membuka gerbang bagi perempuan menjadi seorang pemimpin. Hal ini berkaitan dengan bimbingan dan konseling di standar kompetensi kemandirian peserta didik yaitu pada aspek perkembangan; kesadaran gender. Serta mampu mengembangkan tugas-tugas perkembangan yaitu pada persiapan mandiri, pemilihan dan latihan jabatan. Selain itu

berkaitan juga dengan layanan dan fungsi bimbingan dan konseling yaitu layanan penempatan dan penyaluran yang mampu menyediakan kebutuhan, potensi, bakat dan minat siswa yang diselenggarakan di sekolah dan fungsi pemeliharaan dan pengembangan. Mengingat kurangnya pemimpin perempuan disebabkan oleh adanya stereotip sosial yang menghambat perempuan untuk memimpin, maka bimbingan dan konseling memberi perluasan akses perempuan dalam mengembangkan kegiatan OSIS.

Berdasarkan hal-hal tersebut, maka rumusan masalah dalam penelitian ini ialah "Gaya kepemimpinan apa yang digunakan ketua osis perempuan pada osis di SMA se-Jakarta Timur?". Tujuan diadakan penelitian ini yaitu mengetahui gaya kepemimpinan perempuan studi pada ketua OSIS di SMA se-Jakarta Timur.

\section{Kajian Teori \\ Hakikat Kepemimpinan}

Kepemimpinan adalah (cara atau teknik=gaya) yang digunakan pemimpin dalam mempengaruhi pengikut atau bawahannya dalam melakukan kerja sama mencapai tujuan yang telah ditentukan. Menurut Yukl mencoba merangkum definisi-definisi lainnya hingga sampai satu kesimpulan bahwa kebanyakan definisi mengenai kepemimpinan adalah berdasarkan asumsi bahwa kepemimpinan meliputi proses dima- 
na keinginan untuk mempengaruhi orang digunakan oleh seseorang terhadap orang lain untuk membimbing dan memfasilitasi aktivitas dan hubungan dalam sebuah kelompok atau organisasi. Berdasarkan berbagai pengertian tentang kepemimpinan, maka dapat diambil suatu kesimpulan bahwa kepemimpinan adalah faktor yang sangat penting dalam organisasi dimana pemimpin mempunyai kemampuan untuk dapat mempengaruhi bawahan tanpa adanya paksaan dalam melakukan kerja sama mencapai tujuan yang telah ditentukan oleh semua anggota.

\section{Gaya Kepemimpinan}

Gaya kepemimpinan adalah suatu cara atau perilaku yang dipergunakan oleh seorang pemimpin dalam mempengaruhi, mengarahkan, mendorong, dan mengendalikan bawahannya dalam rangka pencapaian tujuan organisasi secara efisien dan efektif.

Menurut Ronald Lippit and Ralp K. White bahwa gaya kepemimpinan membahas berbagai hubungan antara perilaku pemimpin yang berbeda, yaitu perilaku otoriter, demokratis, dan Laissez-faire, yaitu :

1. Gaya otoriter, yaitu gaya kepemimpinan otoritarian dapat pula disebut tukang cerita. Pemimpin otokritas biasanya merasa bahwa mereka mengetahui apa yang mereka inginkan dan cenderung mengekspresikan kebutuhan-kebutuhan tersebut dalam bentuk perintah-perintah langsung kepada bawahan.

2. Gaya demokratis, yaitu gaya kepemimpinan yang dikenal pula sebagai gaya partisipatif. Gaya ini berasumsi bahwa para anggota organisasi yang diambil bagian secara pribadi dalam proses pengambilan keputusan akan lebih memungkinkan sebagai suatu akibat mempunyai komitmen yang jauh lebih besar pada sasaran dan tujuan organisasi. Pendekatan tidak berarti para pemimpin tidak membuat keputusan, tetapi justru seharusnya memahami terlebih dahulu apakah yang menjadi sasaran organisasi sehingga mereka dapat mempergunakan pengetahuan para anggotanya.

3. Gaya laissez Faire yaitu gaya kepemimpinan kendali bebas. Pendekatan ini bukan berarti tidak adanya sama sekali pimpinan. Gaya ini berasumsi bahwa suatu tugas disajikan kepada kelompok yang biasanya menentukan teknik-teknik mere- ka sendiri guna mencapai tujuan tersebut dalam rangka mencapai sasaran dan kebijakan organisasi.

\section{Kepemimpinan Perempuan}

Kepemimpinan perempuan di sini dapat diartikan sebagai suatu kemampuan atau kecakapan khusus yang dimiliki seorang perempuan, dengan atau tanpa pengangkatan resmi dapat mempengaruhi dan menggerakkan orang lain (individu maupun kelompok) agar bersedia melakukan usaha bersama yang mengarahkan pada pencapaian sasaran dan tujuan tertentu. Dari penjelasan tersebut bahwa untuk menjadi seorang pemimpin yang dibutuhkan dan diperhitungkan adalah kemampuannya, bukan apa jenis kelaminnya.

\section{Hakikat OSIS}

OSIS adalah wadah pembinaan generasi muda di lingkungan sekolah yang diterapkan secara terarah dan teratur. OSIS dibentuk dengan tujuan pokok :

1. Menghimpun ide, pemikiran, bakat, kreativitas, serta minat para siswa ke dalam salah satu wadah yang bebas dari berbagai macam pengaruh negative dari luar sekolah

2. Mendorong sikap, jiwa dan semangat kesatuan dan persatuan diantara para siswa, sehingga timbul satu kebanggaan untuk mendukung peran sekolah sebagai tempat terselenggaranya proses belajar mengajar.

3. Sebagai tempat dan sarana untk berkomunikasi, menyampaikan pemikiran, dan gagasan dalam usaha untuk mematangkan kemampuan berfikir, wawasan, dan pengambilan keputusan.

\section{Metodologi Penelitian}

Penelitian ini dilakukan di SMA se-Jakarta Timur. Waktu penelitian dilaksanakan dari bulan Januari hingga Mei 2014. Penelitian ini menggunakan metode survey dengan studi deskripstif. Metode ini digunakan untuk menggambarkan suatu sifat keadaan yang sementara berjalan pada saat penelitian dilakukan dan memeriksa sebab-sebab dari gejalagejala tertentu.

Populasi pada penelitian ini adalah ketua OSIS SMA di wilayah Jakarta Timur yang berjumlah 123 orang. Teknik pengambilan sampel yang diguna- 
kan adalah purposive sampling merupakan pengambilan sampel yang dilakukan dengan cara mengambil subyek bukan didasarkan atas strata atau daerah, tetapi didasarkan atas adanya tujuan tertentu. sampel penelitian yang terdiri dari ketua OSIS perempuan di SMA wilayah Jakarta timur, ketua OSIS di wilayah Jakarta Timur berjumlah 123 ketua OSIS di SMA wilayah Jakarta Timur sehingga didapatkan 32 orang. Teknik pengumpulan data yang digunakan yaitu Kuesioner atau angket dari gaya kepemimpinan merujuk pada pendapat atau teknik dari Ronald Lippit and Ralp K. White.

Untuk uji coba instrument dalam penelitian ini digunakan pengujian validitas dan reliabilitas menggunakan rumus korelasi point biserial. Kriteria perhitungan dengan jumlah responden uji coba 26 orang $(\mathrm{N}-2=24)$, sehingga rtabel $=0,404$. Berdasarkan hasil perhitungan 94 item pernyataan dengan taraf signifikansi 0,05 maka diperoleh 56 item yang dinyatakan valid dan 38 item yang dinyatakan tidak valid. Agar instrumen lebih proposional maka setiap indikator hanya terdiri dari 2 item pernyataan yang valid sehingga bagi indikator yang terdiri dari 3-5 item akan diambil 2 item yang jumlah validitas paling tinggi, butir-butir yang drop atau tidak va-lid dan telah direvisi pernyataannya sehingga didapat 66 item pernyataan yang final. Untuk perhitungan reliabilitas dengan menggunakan rumus KR-20 diperoleh koefisien reliabilitas sebesar 0,9501.

\section{Hasil dan Pembahasan}

Hasil data dari penyebaran instrumen menyatakan bahwa 10 orang gaya kepemimpinannya otoriter $(31 \%)$. Selanjutnya terdapat 19 orang gaya kepemimpinannya demokratis (59\%) dan 3 orang gaya kepemimpinannya laissez faire (10\%). Maka dapat dilihat pada tabel 4.1 dan grafik 4.1

Tabel 4.1 Data Gaya Kepemimpinan Perempuan pada Ketua OSIS

\begin{tabular}{|c|c|c|}
\hline Gaya Kepemimpinan & Frekuensi & $\mathbf{\%}$ \\
\hline Otoriter & 10 & $31 \%$ \\
\hline Demokratis & 19 & $59 \%$ \\
\hline Laissez Faire & 3 & $10 \%$ \\
\hline Jumlah & $\mathbf{3 2}$ & $\mathbf{1 0 0 \%}$ \\
\hline
\end{tabular}

Pada tabel dan grafik 4.1 diperoleh tiga gaya kepemimpinan, yaitu gaya kepemimpinan otoriter, demokratis dan laissez faire. Gaya kepemimpinan yang dimiliki ketua OSIS perempuan di SMA se-Jakarta Timur cenderung lebih tinggi pada gaya kepemimpinan demokratis, gaya kepemimpinan otoriter cenderung pada posisi sedang dan gaya kepemimpinan laissez faire terdapat di posisi rendah.

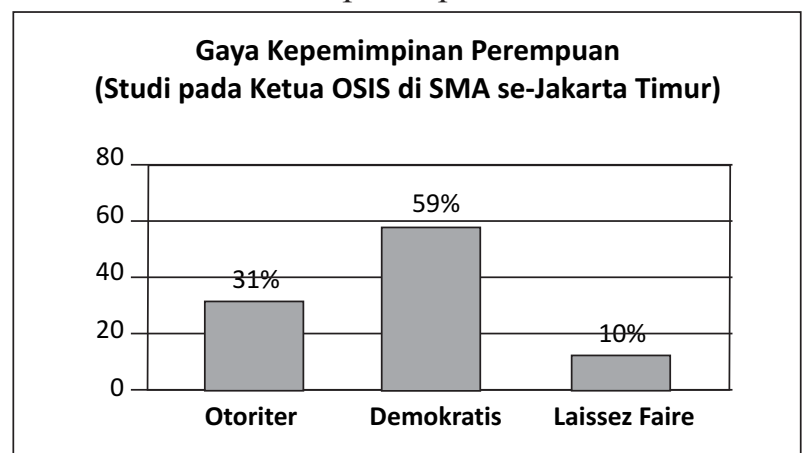

Grafik 4.1 Gaya Kepemimpinan Perempuan (Studi pada Ketua OSIS SMA di Jakarta Timur)

\section{Deskripsi Data Berdasarkan Gaya Kepemimp- inan Perempuan pada Ketua OSIS di SMA per Aspek}

Pemaparan data dilakukan untuk mengetahui gaya kepemimpinan perempuan studi pada ketua OSIS di SMA se-Jakarta Timur. Setiap gaya kepemimpinan masing-masing memiliki empat aspek. Gaya kepemimpinan otoriter dapat dilihat dari hasil perhitungan tiap aspek pada tabel 4.2 dan grafik 4.2 sebagai berikut:

Tabel. 4.2 Aspek pada Gaya Kepemimpinan Otoriter

\begin{tabular}{|c|r|c|}
\hline Aspek & Skor & \% \\
\hline Pengambilan Keputusan & 67 & $14.69 \%$ \\
\hline Pelaksanaan Kegiatan & 117 & $25.65 \%$ \\
\hline Pemberian Tugas & 127 & $27.85 \%$ \\
\hline Pemberian Penghargaan & 145 & $31.79 \%$ \\
\hline Jumlah & $\mathbf{4 5 6}$ & $\mathbf{1 0 0 \%}$ \\
\hline
\end{tabular}

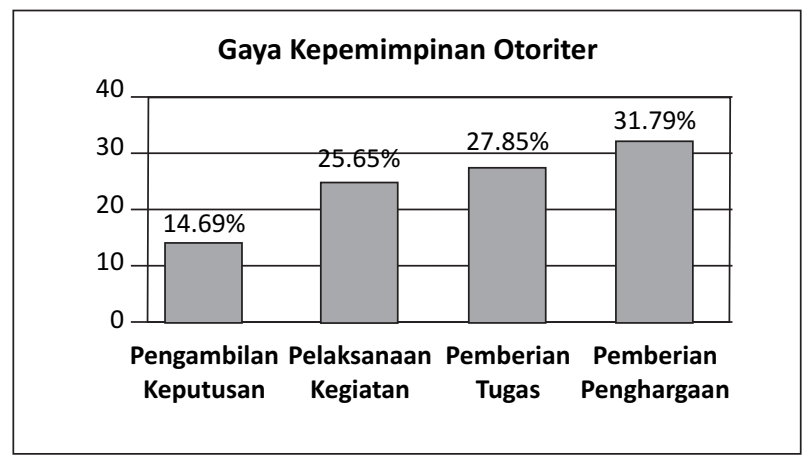

Grafik. 4.2 Gaya Kepemimpinan Otoriter 
Tabel dan grafik 4.2 gaya kepemimpinan otoriter diatas bahwa aspek yang tertinggi yaitu pada aspek ke empat pemberian penghargaan (31.79\%). Hal ini berkaitan dengan butir pernyataan yaitu untuk meningkatkan motivasi, saya lebih senang memberikan kritikan kepada pengurus dan berkaitan dengan ciri gaya kepemimpinan otoriter bahwa pimpinan menuntut prestasi sempurna dari bawahan tanpa syarat sehingga lebih banyak kritik dari pada pujian.

Sedangkan gaya kepemimpinan demokratis yang memiliki 4 aspek dapat dilihat di tabel 4.3 dan grafik 4.3

Tabel. 4.3 Aspek Gaya Kepemimpinan Demokratis

\begin{tabular}{|c|r|c|}
\hline Aspek & Skor & \% \\
\hline Pengambilan Keputusan & 84 & $15.61 \%$ \\
\hline Pelaksanaan Kegiatan & 186 & $34.57 \%$ \\
\hline Pemberian Tugas & 84 & $15.61 \%$ \\
\hline Pemberian Penghargaan & 184 & $34.20 \%$ \\
\hline Jumlah & $\mathbf{5 3 8}$ & $\mathbf{1 0 0 \%}$ \\
\hline
\end{tabular}

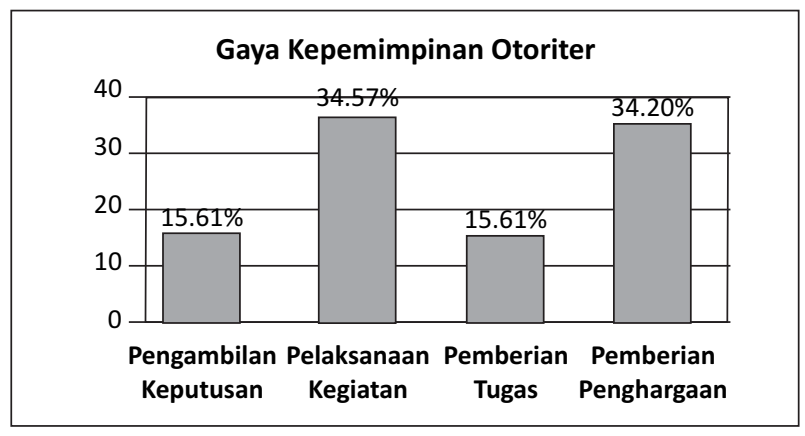

Grafik 4.3 Gaya Kepemimpinan Demokratis perAspek

Pada tabel dan grafik 4.3 diatas gaya kepemimpinan demokratis bahwa aspek yang tertinggi yaitu Cara Pelaksanaan Kegiatan (34.57\%). Hal ini berkaitan dengan butir pernyataan yaitu pada pengurus/anggota OSIS ikut berperan dalam menyampaikan saran atau pendapat dalam pengembangan OSIS dan berkaitan juga dengan karakteristik gaya kepemimpinan demokratis dimana kegiatan dilakukan secara bersama-sama untuk mencapai tujuan kelompok.

Gaya kepemimpinan Laissez faire yang sama memiliki 4 aspek dapat dilihat di tabel 4.4 dan grafik 4.4 sebagai berikut:
Tabel. 4.4 Aspek Gaya Kepemimpinan Laissez Faire

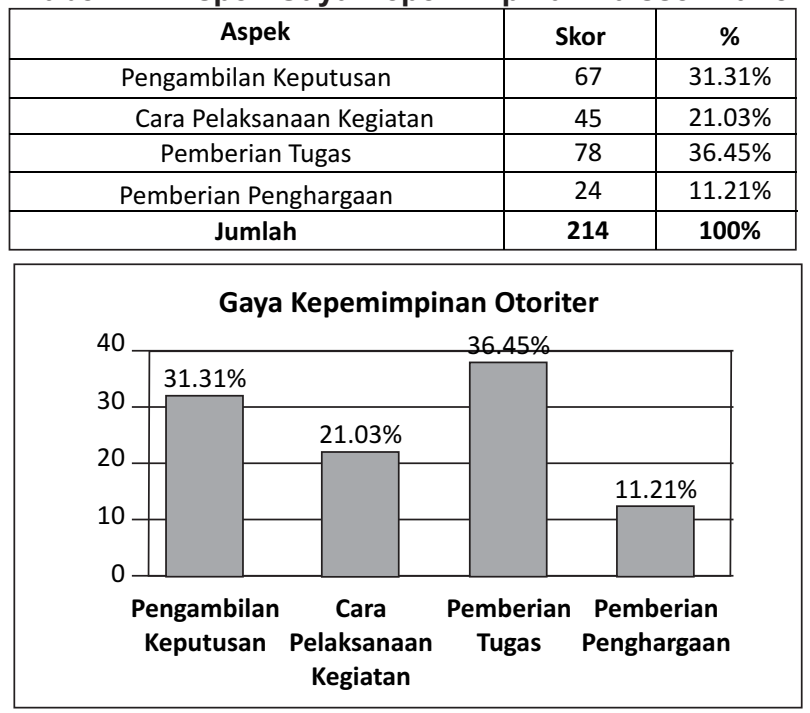

Grafik 4.4 Aspek Gaya Kepemimpinan Laissez Faire

Pada tabel dan grafik 4.4 gaya kepemimpinan laissez faire bahwa aspek yang tertinggi yaitu pemberian tugas $(36.45 \%)$. Hal ini berkaitan dengan butir pernyataan yaitu anggota OSIS diberikan peluang untuk mengembangkan dirinya di dalam kegiatan-kegiatan OSIS, sehingga aspek ini lebih tinggi dari pada aspek lain karena pengurus/anggota OSIS yang lebih banyak berperan dalam kegiatan-kegiatan OSIS.

\section{Kesimpulan dan Saran Kesimpulan}

Berdasarkan hasil penelitian yang telah dilakukan oleh peneliti mengenai gaya kepemimpinan perempuan (studi pada ketua OSIS di SMA se-Jakarta Timur). Hasil data dari penyebaran instrumen gaya kepemimpinan perempuan, hasil yang telah didapatkan bahwa gaya kepemimpinan perempuan pada ketua OSIS di SMA lebih banyak terdapat pada gaya kepemimpinan demokratis sebanyak 19 orang, bahwa perempuan cenderung mengambil gaya kepemimpinan yang lebih demokratis karena pada aspek gaya kepemimpinan perempuan demokratis yang tertinggi terdapat pada aspek cara pelaksanaan kegiatan dimana ketua OSIS mendorong partisipasi berbagi kekuasaan dan informasi kepada bawahan, serta berupaya meningkatkan harga diri pengikutnya. 


\section{Saran}

1. Bagi Ketua OSIS perempuan diharapkan OSIS sebagai gerbang bagi perempuan menjadi seorang pemimpin, peluang akses bagi perempuan untuk menjadi pemimpin, serta mempunyai kesempatan kesetaraan bagi perempuan dan laki-laki untuk menjadi pemimpin.

2. Bagi guru BK dapat memfasilitasi siswa melalui layanan dan fungsi BK untuk melakukan layanan penempatan dan penyaluran yang mampu menyediakan pemenuhan kebutuhan siswa seperti potensi, bakat dan minat, sehingga bagi siswa perempuan mempunyai peluang untuk menjadi pemimpin di berbagai bidang organisasi di sekolah. Guru BK juga dapat memberikan informasi mengenai kepemimpinan perempuan bahwa pemimpin perempuan memiliki kekhasan dalam kepemimpinan.

3. Bagi Peneliti selanjutnya, dapat membuat penilaian sejenis berdasarkan gaya kepemimpinan perempuan ketua OSIS di SMA yang masih jarang perempuan mendapatkan kesempatan untuk memimpin. Peniliti selanjutnya juga dapat meneliti variabel-variabel, perbedaan gaya kepemimpinan laki-laki dan perempuan ketua OSIS lanjut dari penelitian ini.

\section{Daftar Pustaka}

Azizah al-Hibri, et al. 2001. Wanita Dalam Masyarakat Indonesia; Akses pemberdayaan dan Kesempatan. Yogyakarta: Sunan Kalijaga Press.

Eka Hastiana. 2007. Skripsi : Studi Deskriptif Persepsi Mahasiswa terhadap kepemimpinan Perempuan di Organisasi Mahasiswa Universitas Negeri Jakarta. UNJ: Jakarta

Desrina. Penelitian Dosen. Analisis Kepemimpinan Perempuan di UNJ(Studi terhadap KepemimpinanPerempuan di UNJ).(Universitas Negeri Jakarta; 2012)
Feldmen, R.S. 1998. Social Psychology 2nd ed. New Jersey, USA. Allyn and Bacon

Febri M.L. Tobing. 2002. Gambaran karakteristik kepemimpinan perempuan dalam rumah tangga. Universitas Indonesia; Jakarta

Harbani Pasolong. 2008. Kepemimpinan Birokrasi. Bandung; Alfabeta.

Kamla Bhasin. 2001. Memahami Gender. Teplok Press; Jakarta.

Kartono,kartini. 2001. Pemimpin dan Kepemimpinan. PT RajaGrafindo Persada;Jakarta

Klenke, Karin. 1996. Women and Leadership : a contextual perspectiv. New York, USA. Springer Publishing Company

Penataan Pendidikan Profesional konselor dan Layanan Bimbingan dan Konseling dalam Jalur Pendidikan Formal. Deperteman Pendidikan Nasional, 2008.

Prayitno. 1999. Dasar-dasar Bimbingan dan Konseling. Rineka Cipta, Jakarta

Miftah Thoha. 1999. Kepemimpinan dalam Manajemen. RajaGrafindo Persada; Jakarta

Nuri Herachwati dan Bhaskaroga Dwiatmaja Basuki. jurnal Makalah Ekonomi Tahun. XXII, No. 2 Agustus 2012

Sardi, Efendi. Skripsi: Studi Deskriptif Gaya Kepemimpinan Ketua Badan Eksekutif Mahasiswa Universitas Negeri Jakarta. UNJ; Jakarta, 2004

Soekarso, Sosro Agus, Putong Iskandar, Hidayat Cecep. 2010. Teori Kepemimpinan. Mitra Wacana Media; Jakarta

Suhaesimi Arikunto, 2002. Prosedur Penelitian: Suatu Pendekatan Praktik. Jakarta: Rhineka Cipta.

Tikno Lensufiie. 2010. Leadership untuk Profesional dan Mahasiswa.Jakarta; ESENSI ERLANGGA.

Udaya, Yusuf. 1998. Kepemimpinan dalam Organisasi edisi bahasa indonesia dari Leadership in Organizations,3e. Jakarta: Prenhallindo

Yukl, Gary. Kepemimpinan dalam Organisasi (terjemahan). Jakarta; Prenhallindo 